\title{
Comparison of Auxiliary Diagnostic Methods in Pulmonary Embolism
}

\section{Pulmoner Embolide Yardımcı Tanı Yöntemlerinin Karşılaştırılması}

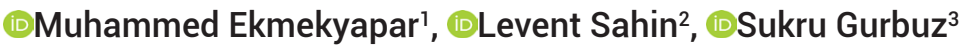 \\ 'Malatya Education and Research Hospital,Department of Emergency Medicine, Malatya, Turkey \\ ${ }^{2}$ Kafkas University, School of Medicine, Department of Emergency Medicine, Kars, Turkey \\ ${ }^{3}$ Inonu University, School of Medicine,Department of Emergency Medicine, Malatya, Turkey \\ Copyright@Author(s) - Available online at www.dergipark.org.tr/tr/pub/medr \\ Content of this journal is licensed under a Creative Commons Attribution-NonCommercial 4.0 International License.
}

\begin{abstract}
Aim: We investigated the importance of auxiliary diagnostic methods in cases when computed tomography pulmonary angiography (CTPA) cannot be used in pulmonary embolism (PE) with a high mortality rate.

Materials and Methods: Patients were selected after the exclusion criteria were applied in a sample created from a single center. A total of 86 patients included in our study were examined in terms of clinical features, auxiliary diagnostic methods, anticoagulant use, and hospitalization and discharge status according to the massive or segmental involvement of PE in CTPA.

Results: The mean age of the patients was $52.29 \pm 14.14$ years. According to the CTPA results, there were $46(53.5 \%)$ patients with massive involvement and $40(46.5 \%)$ patients with segmental involvement. While there were $38(82.6 \%)$ patients with massive involvement whose right chambers of the heart were dilated in echocardiography (ECHO) results, there were $19(47.5 \%)$ patients with segmental involvement. There was a statistical significance between the massive involvement of CTPA and ECHO result ( $p=0.001)$. Conclusion: ECHO may be preferred as an auxiliary radiological method in the diagnosis of PE in emergency departments (ED), especially in massive embolisms.
\end{abstract}

Keywords: Pulmonary embolism; massive; segmental; echocardiography

Öz

Amaç: Mortalite oranı yüksek pulmoner embolide (PE) bilgisayarlı tomografı pulmoner anjiyografınin (BTPA) kullanılamadığı durumlarda yardımcı tanı yöntemlerinin önemini araştırdık.

Materyal Metod: Hastalar tek merkezden oluşturulan bir örneklemde dışlama kriterleri uygulandıktan sonra toplanmış oldu. Çalışmamıza dahil edilen toplam 86 hasta BTPA'da PE'nin masif ya da segmental tutulumuna göre klinik özellikleri, yardımcı tanı yöntemleri, antikoagülan kullanımı ve yatış taburculuk durumuna göre incelendi.

Bulgular. Hastaların yaş ortalaması $52.29 \pm 14.14$ yıl idi. BTPA sonucuna göre masif tutulumu olan 46 (\%53.5) ve segmental tutulumu olan toplam 40 (\%46.5) hasta vardı. Masif tutulumlarda ekokardiyografı (EKO) sonucunda sağ kalp boşlukları dilate olan 38 (\%82.6) hasta varken; segmental tutulumlarda ise $19(\% 47.5)$ hasta vardı. BTPA'nin masif tutulumu ile EKO sonucu arasında istatistiksel bir anlamlılık vardı $(\mathrm{p}=0,001)$.

Sonuç: Acil servislerde PE tanısında özelikle de masif embolilerde yardımcı radyolojik yöntem olarak EKO tercih edilebilir.

Anahtar Kelimeler. Pulmoner emboli; masif; segmental; ekokardiyografi

Geliş Tarihi / Received: 18.05.2021 Kabul Tarihi / Accepted: 22.07.2021

Sorumlu Yazar /Corresponding Author. Muhammed Ekmekyapar, Malatya Education and Research

Hospital,Department of Emergency Medicine, Malatya, Turkey, E-mail: m_ekmekyapar@hotmail.com 


\section{INTRODUCTION}

Acute pulmonary embolism (PE) is a common cause of acute-onset chest pain that occurs in the emergency department (ED) (1). Patients most frequently present with complaints of shortness of breath, chest pain, cough, hemoptysis, palpitation, tachypnea, and cyanosis (2). It is one of the most important causes of death in hospitalized patients and is responsible for approximately $15 \%$ of deaths. However, in case of late diagnosis or misdiagnosis, this rate can increase up to $30 \%$ (3).

Radiological methods such as chest radiography, ventilation/perfusion(V/P) scintigraphy, echocardiography (ECHO), computed tomography pulmonary angiography (CTPA), conventional pulmonary angiography, and magnetic resonance (MR) angiography are preferred for diagnosis. PE develops due to thromboisis in the deep veins of the legs in more than $3 / 4$ of the cases (4). Color Doppler ultrasonography (CDUS) is the most commonly used imaging method in the diagnosis of DVT (5).

CT pulmonary angiography (CTPA) takes a significant place in the diagnosis of PE since it shows embolism directly and is a fast and non-invasive method (6). Furthermore, Wells scoring, which is the most preferred scoring method for PE diagnosis, is also applied (7). To date, many studies have been conducted on the relationship between the PE clinical picture and diagnostic methods $(8,9)$.

In our study, we investigated which of the other auxiliary diagnostic methods such as posteroanterior chest X-ray (PA CXR), ECHO and lower extremity venous color doppler ultrasonography would be more helpful in diagnosing $\mathrm{PE}$ according to the CTPA result.

\section{MATERIAL AND METHOD}

This study was initiated after the ethics committee approval was obtained from Inönü University Scientific Research and Publication Ethics Committee with the decision dated 05.03.2019 and numbered 2019/5-9.

\section{Case Selection and Data Collection}

In this study, patients diagnosed with pulmonary embolism in the ED of a university hospital for a period of 1 year between 01.01.2018 and 31.12.2018 were examined. Pregnant women, patients with contrast material allergy and renal insufficiency were accepted as exclusion criteria. Patients with normal D-dimer levels (200-500 ng/ $\mathrm{ml})$ or D-dimer levels below normal $(<200 \mathrm{ng} / \mathrm{ml})$ were not included in the study (10).

Eighty-six patients who were diagnosed with PE after the exclusion criteria were included in the study. Systemic physical examinations of the patients admitted to the ED were performed by emergency medicine specialists. Patients' age, sex, admission complaints, anticoagulant use, Wells scores, direct chest radiographs, ECHO, Doppler USG, CTPA (massive or segmental involvement), and hospitalization-discharge status were evaluated.

\section{Statistical Analysis}

The statistical analysis of the data obtained was carried out using the IBM SPSS (version 20.0; SPSS ${ }^{\mathrm{T}}{ }^{\mathrm{M}}$, Chicago, IL) program. The numerical data obtained by measurement were presented as mean and standard deviation, and the categorical data obtained by counting were presented as number ( $\mathrm{n}$ ) and percentage (\%). Pearson's chi-square test was used for the statistical analysis of categorical variables, and the Mann-Whitney $U$ test was used for the analysis of independent variables that did not exhibit normal distribution. The value of $p<0.05$ was considered significant in all tests.

\section{RESULT}

Our study was conducted with a total of 86 patients, 40 (46.5\%) males and 46 (53.5\%) females, after all exclusion criteria were applied. The mean age of the patients was $52.29 \pm 14.14$ years. When we examined the patients according to their complaints, we observed that the most common complaint was shortness of breath, which was followed by chest pain, cough, syncope, hemoptysis, and leg pain, respectively (Table 1 ).

According to the patients' CTPA results (massive and segmental involvement), sex, Wells score classifications, PA CXR results, ECHO results, the presence of DVT on Doppler USG, anticoagulant drug use, and hospitalization status were statistically compared bythe chi-square test.

There were a total of 46 (53.5\%) patients with massive involvement, according to the CTPA result. Of these, 22 $(47.8 \%)$ were male, and $24(52.2 \%)$ were female. Again, according to the CTPA results, 18 (45\%) of 40 (46.5\%) patients with segmental involvement were male, and 22 $(55 \%)$ were female. No statistical significance was found between the CTPA result and sex $(p=0.482)$ (Table 2).

The number of patients whose Wells score was accepted as moderate was 60 (69.8\%), and the number of patients whose Wells score was accepted as high was 26 (30.2\%). In massive involvement, there were 29 (63\%) patients with a moderate Wells score and $17(37 \%)$ patients with a high Wells score. In segmental involvement, there were $31(77.5 \%)$ patients with a moderate Wells score and 9 $(22.5 \%)$ patients with a high Wells score $(p=0.111)$ (Table $2)$. On the PA CXR, the number of patients with infiltration was $59(68.6 \%)$, the number of patients without infiltration was $14(16.3 \%)$, and the number of patients with effusion was $13(15.1 \%)$. In massive involvement, there were $37(80.4 \%)$ patients with infiltration, $5(10.9 \%)$ patients without infiltration, and 4 (8.7\%) patients with effusion on the PA CXR. In segmental involvement, there were 22 (55\%) patients with infiltration, 9 (22.5\%) patients without infiltration, and 9 (22.5\%) patients with effusion on the PA CXR $(p=0.039)$ (Table 2).

While the number of patients with normal ECHO results was $29(33.7 \%)$, the number of patients with dilated right heart chambers was 57 (66.3\%). In massive involvement, there were $8(17.4 \%)$ patients with normal $\mathrm{ECHO}$ results 
and $38(82.6 \%)$ patients with dilated right heart chambers. In segmental involvement, there were 21 (52.5\%) patients with normal ECHO results and $19(47.5 \%)$ patients with dilated right heart chambers $(p=0.001)$ (Table 2). There were 50 (58.1\%) patients without DVT and 36 (41.9\%) patients with DVT in Doppler USG results. In massive involvement, there were $23(50.0 \%)$ patients without DVT and $23(50.0 \%)$ patients with DVT on Doppler USG. In segmental involvement, there were $27(67.5 \%)$ patients without DVT and 13 (32.5\%) patients with DVT on Doppler USG $(p=0.077)$ (Table 2).

Among all patients, the rate of anticoagulant drug use was very low. There were only $16(18.6 \%)$ patients using anticoagulants. In patients with massive involvement, there were $36(78.3 \%)$ patients not using anticoagulants and $10(21.7 \%)$ patients using anticoagulants. In segmental involvement, there were $34(85 \%)$ patients not using anticoagulants and 6 (15\%) patients using anticoagulants. Drug use had no statistical significance for both involvements $(p=0.423)$ (Table 3$)$.

The total number of patients hospitalized was 81 (94.2\%), and the total number of patients discharged was $5(5.8 \%)$. Forty-six (100\%) of the patients with massive involvement were hospitalized. In segmental involvement, the number of patients hospitalized was $35(87.5 \%)$, and the number of patients discharged was $5(12.5 \%)(p=0.019)$ (Table 3$)$.

Table 1. Complaints of the patients during admission to the ED

\section{Complaints}

Shortness of breath

Chest pain

Cough

Syncope

Hemoptysis

Leg pain

\section{Number}

52

14

12

4

3

1

\section{Percentage}

$60.4 \%$

$16.3 \%$

$13.9 \%$

$4.7 \%$

$3.5 \%$

$1.2 \%$

Table 2. Comparison of CTPA results with clinical variables

CTPA Result

Variables

Sex

Wells Scale

PA CXR

ECHO Result

Doppler USG
Massive

$22(47.8 \%)$

$24(52.2 \%)$

$29(63 \%)$

$17(37 \%)$

$37(80.4 \%)$

$5(10.9 \%)$

$4(8.7 \%)$

$8(17.4 \%)$

Dilated right heart chambers

Without DVT

With DVT
$38(82.6 \%)$ *

$23(50.0 \%)$

$23(50.0 \%)$
Segmental

$18(45 \%)$

22 (55\%)

31 (77.5\%)

9 (22.5\%)

22 (55\%)

9 (22.5\%)

9 (22.5\%)

21 (52.5\%)

$19(47.5 \%)$

27 (67.5\%)

$13(32.5 \%)$
Total

40 (46.5\%)

46 (53.5\%)

60 (69.8\%)

26 (30.2\%)

59 (68.6\%)

$14(16.3 \%)$

$13(15.1 \%)$

29 (33.7\%)

57 (66.3\%)

50 (58.1\%)

36 (41.9\%) $p$-value

0.482

0.111

0.039

0.001

0.077

PA CXR: Posteroanterior chest X-ray, ECHO: Echocardiography, USG: Ultrasonography, DVT: Deep vein thrombosis

Table 3. Comparison of the drug use and hospitalization variables according to CTPA results

\section{CTPA Result}

Drug Use Status

Hospitalization

Status

Massive
$10(21.7 \%)$
$36(78.3 \%)$
$46(100 \%)$
$0(0 \%)$

Using anticoagulants

Not using anticoagulants

Hospitalization

Discharge

Segmental
$6(15 \%)$
$34(85 \%)$
$35(87.5 \%)$
$5(12.5 \%)$

Total
$16(18.6 \%)$
$70(81.4 \%)$
$81(94.2 \%)$
$5(5.8 \%)$

p-value

0.423

0.019 
The mean hospitalization duration in the services was 9.62 days, and the mean hospitalization duration in intensive care units was 3.30 days. All patients with massive involvement were admitted to the service or intensive care unit. However, five patients with segmental involvement were discharged outpatient without admission to the pulmonology service. Upon examining the hospitalization duration in the intensive care unit, we observed that 16 patients with massive involvement and 26 patients with segmental involvement were never admitted to the intensive care unit.

\section{DISCUSSION}

$P E$ is a difficult-to-diagnose lung disease that causes about 300,000 deaths annually in the United States of America (11). It is very important to make a definitive diagnosis to prevent this fatal condition. It is difficult to diagnose PE without specific clinical and physical examination findings. Therefore, some diagnostic tests are needed. Arterial blood gas, D-dimer, biochemical markers, electrocardiography, and PA CXR contribute to the diagnosis, albeit limited, in patients with suspected PE (12).

$P E$ is a potentially fatal disease resulting in obstruction of the lung blood flow and perfusion impairment due to an embolism (13). PE is also considered an acute complication of DVT (14). While DVT has an annual incidence of $0.1 \%$ in the general population, it has a rate of more than $1 \%$ in hospitalized patients (15). Especially in proximal DVTs, Doppler USG has a sensitivity of more than $90 \%$ and a specificity of $95 \%$. However, DVT can be detected in approximately $30-50 \%$ of patients diagnosed with PE (16). In another study, bilateral lower extremity Doppler USG performed on patients diagnosed with PE revealed thrombus in the lower extremity in $44.4 \%$ of the cases (12). In our study, we detected DVT at a similar rate in $41.9 \%(n=36)$ of PE patients in line with the literature.

PE can be observed as mild shortness of breath and can even be asymptomatic, as well as leading to death as a result of sudden cardiac arrest (17). It has a wide clinical spectrum and can often occur with different combinations such as shortness of breath, pleuritic chest pain, respiratory failure, hypoperfusion, and hemodynamic instability (17). Hemoptysis and cough may also occur, but they are usually associated with other underlying causes (18). In our study, the most common complaint of the patients was shortness of breath, while the second most common complaint was chest pain.

The mean age of the incidence of the disease is $69.3 \pm 16.0$ years, and there is no significant difference in terms of sex (19). However, although the sex ratios were close to each other in our study, the mean age was lower $(52.29 \pm 14.14$ years).

ECHO, which can be applied bedside by helping to diagnose $\mathrm{PE}$ in $\mathrm{ED}$, is now indispensable. ECHO may show right ventricular dysfunction, although it cannot prove the embolism completely (20). In the study conducted by
Mazen S et al., dilatation in the right ventricle (55\%) and right ventricular dysfunction (85\%) were observed in the $E C H O$ evaluation of patients with suspected PE $(p=0.001)$ (21). The right ventricular dilatation was observed most commonly in the $\mathrm{ECHO}$ evaluation of patients in our study $(p=0.001)$.

Although PA CXR is not a priority for diagnosis, it can support other diagnostic methods. In a study, the most common chest radiography findings were parenchymal infiltration in $37.3 \%(n=22)$ and pleural effusion in $35.6 \%$ $(n=21)$, but no finding was detected in $33.9 \%(n=20)$ of the patients (22). In our study, parenchymal infiltration was observed most commonly, at a rate of $68.6 \%(n=59)$, in line with the literature, on the PA CXR.

With technological advances in recent years, CTPA can directly show the thrombus in the pulmonary artery bed up to the segmental level (23). Although acute PE cannot be observed with the help of CTPA, which we prefer for definite and rapid diagnosis of PE in ED, it can show alternative diagnoses for the patient's clinical picture (24). In a study evaluating the detection of acute PE, when CTPA was compared with pulmonary angiography, which is the gold standard, it was observed that CTPA had $91 \%$ accuracy (25). In the study carried out by Erdal et al., it was reported that $68 \%(n=64)$ of the thrombus were central (main and lobar arteries), and $32 \%(n=30)$ were peripheral (segmental and subsegmental arteries) (22). Our study was quite compatible with the literature, and we detected massive embolism in $53.5 \%(n=46)$ of the patients diagnosed with PE and segmental embolism in $46.5 \%(n=40)$.

In the present study, we also compared the $\mathrm{ECHO}$ results according to whether PE was massive or segmental. The right heart chambers were dilated in $82.6 \%$ of patients with massive $P E$, while the right heart chambers were dilated in $47.5 \%$ of patients with segmental PE.

As a result of a study performed according to Wells scoring, $14.75 \%$ of the patients were evaluated as those with high probability, $52.46 \%$ as those with moderate probability, and $32.79 \%$ as those with low probability (26). In our study, there were no patients with low probability in the Wells scoring. The Wells score of most patients $(69.8 \%)$ was moderate. There were more patients $(63 \%)$ with moderate Wells scores in both massive and segmental involvement.

Especially the anticoagulant use status of patients also affects $P E$. The main goal of PE treatment after discharge is to prevent the recurrence of fatal or non-fatal venous thromboembolism (VTE) with oral anticoagulants (27). Although these agents are very effective in preventing VTE recurrence, new thromboembolic events occur at an estimated rate of $3.3 \%(28)$, while fatal PE occurs in $1.5 \%$ of patients under treatment (29). In another study conducted with 124 patients, 30 patients were diagnosed with pulmonary embolism according to the results of CTPA performed on 70 patients with moderate and high probability determined as a result of V/P scintigraphy. It 
was observed that $24(80 \%)$ of 30 patients diagnosed with PE were not using any drug for prophylaxis (30). In our study, 10 (62.5\%) of 16 patients were using anticoagulants due to PE history. The remaining $6(37.5 \%)$ patients were using anticoagulants for other reasons (atrial fibrillationflutter, heart valve replacement, stroke, etc.). Of the total patients, only five patients died. Of these 5 patients who died, 4 did not have a history of anticoagulant use, and 1 patient was using anticoagulants due to previous $\mathrm{PE}$. In light of this information in the literature $(28,29)$, we can say that the use of oral anticoagulants significantly reduces the development of recurrent $\mathrm{PE}$, especially the development of fatal PE.

In the study conducted by Baydın et al. with 102 patients, $21.6 \%$ of the cases were massive $\mathrm{PE}$, and $78.4 \%$ were segmental PE. Moreover, all massive and segmental cases were hospitalized (31). In our patients, all of the patients with massive involvement $(n=46)$ and those with segmental involvement $(n=35)$, except for 5 patients (discharge), were hospitalized.

\section{Limitation of the Study}

The main limiting factor is that our study does not reflect the general population due to the small number of patients included. Furthermore, the fact that it could not be carried out in a multi-centered manner is also a limiting factor.

Finally, another limitation is that pulmonary angiography, which is known as the gold standard in diagnosis, could not be performed.

\section{CONCLUSION}

$P E$ is a disease that is difficult to diagnose in ED. Although CTPA is most commonly used in diagnosis, we cannot use CTPA in patients with contrast material allergy and renal insufficiency and pregnant women. Among the auxiliary radiological methods in diagnosis, $\mathrm{ECHO}$, which can be used as a non-invasive and bedside method with ease of application and accessibility, is now indispensable in ED, especially in the diagnosis of massive PE.

Financial disclosures: All authors declare no financial support.

Conflict of Interest: The authors declare that they have no competing interest.

Ethical approval: This study was initiated after the ethics committee approval was obtained from Inönü University Scientific Research and Publication Ethics Committee with the decision dated 05.03.2019 and numbered 2019/5-9.

\section{REFERENCES}

1. Beckman MG, Hooper WC, Critchley SE, et al. Venous thromboembolism: a public health concern. Am J Prev Med. 2010;38:495-501.

2. Özsu S, Özlü T, Bülbül Y. Pulmonary thromboembolism based on the Turkish national data. Tuberculosis Thorax J. 2009;57:466-82.
3. White $\mathrm{RH}$. The epidemiology of venous thromboembolism. Circulation. 2003;107 (Suppl1):14-8.

4. Elias A, Colombier D, Victor G, et al. Diagnostic performance of complete lower limb venous ultrasound in patients with clinically suspected acute pulmonary embolism. Thromb Haemost. 2004;91:187-95.

5. Kearon C, Ginsberg JS, Hirsh J. The role of venous ultrasonography in the diagnosis of suspected deep venous thrombosis and pulmonary embolism. Ann Intern Med. 1998;129:1044-9.

6. Konstantinides SV, Torbicki A, Agnelli G, et al. 2014 ESC guidelines on the diagnosis and management of acute pulmonary embolism. EurHeart J. 2014;35:3033-69.

7. van der Hulle T, Cheung WY, Kooij S, et al. Simplified diagnostic management of suspected pulmonary embolism (the YEARS study): a prospective, multicentre, cohort study. Lancet. 2017;390:289-97.

8. Oz I.I, Serifoglu I, Altınsoy B, et al. Diagnostic imaging in acute pulmonary embolism. J Chest Diseasesand Critical. Care. 2014;1:151-6.

9. Sebih A.L.P, Özyurt S, Kara B.Y, et al. Determination of factors affecting the survival in patients with pulmonary thromboembolism. Journal of Harran University Medical Faculty. 2019;16:470-7.

10. Doolittle RF, Pandi L. Probingthe beta-chain hole of fibrinogen with synthetic peptides that differ at their amino termini. Biochemistry. 2007;46:10033-8.

11. Wendelboe AM, Raskob GE. Global burden of thrombosis: epidemiologic aspects. Circ Res. 2016;118:1340-47.

12. Doğan C, Comert S.S, Caglayan B, et al. Retrospective Evaluation of pulmonary thromboembolism cases. Journal of Izmir Chest Hospital. 2016;30:15-21.

13. Yan $\mathrm{C}$, Wang $\mathrm{X}, \mathrm{Su} \mathrm{H}$, et al. Recent progress in research on the pathogenesis of pulmonary thromboembolism: an old story with new perspectives. Hindawi Bio Med Research International Volume 2017, Article ID 6516791, 10 pages

14. Kobberøe Søgaard K, Schmidt M, Pedersen L, et al. 30-year mortality after venous thromboembolism: a populationbased cohort study. Circulation. 2014:2;130:829-36.

15. Welsh JD, Hoofnagle MH, Bameza S, et al. Hemodynamic regulation of perivalvular endothelial gene expression prevents deep venous thrombosis. J Clin Invest. 2019;129:5489-500.

16. Ipekci A. Pulmonary Embolism. Phnx Med J 2019:1;51-63.

17. Becattini C, Agnelli G. Risk stratification and management of acute pulmonary embolism. Hematology Am Soc Hematol Educ Program. 2016;1:404-12.

18. Ishaaya E, Tapson VF. Advances in the diagnosis of acute pulmonary embolism. Version 1. F1000Res. 2020; 9: F1000 Faculty Rev-44. Published online 2020 Jan 24.

19. Yurtseven A, Tatlı M, Altintop I. Pulmonary Embolism is Enigmatic Problem in Emergency Service: Performance of Wells Score, Geneva Score and Other Test for PE. J Anatolian Med Res. 2017;2:36-44.

20. Barrios D, Morillo R, Lobo JL, et al. Assessment of right ventricular function in acute pulmonary embolism. Am 
Heart J. 2017;185:123-9.

21. Albaghdadi MS, Dudzinski DM, Giordano $N$, et al. Cardiopulmonary Exercise Testing in Patients Following Massive and Submassive Pulmonary Embolism. J Am Hear Assoc. 2018;7: e006841.

22. In E, Turgut T, Kalkan M, et al. The Relationship Between Computed Tomography Pulmonary Angiography Findings and Right Ventricular Dysfunction in Patients with Pulmonary Embolism. Turkish Thoracic J. 2014;15:117-21.

23. Selimoglu Sen H, Abakay O. Current diagnosis and treatment in pulmonary thromboembolism. J Clin Explnvest. 2013;4:405-10.

24. Sin D, Lennan GM, Rengier $F$, et al. Acute pulmonary embolism multimodality imaging prior to endovascular therapy. Int J Cardiovasc Imaging. 2021;37:343-58.

25. Winer-Muram HT, Rydberg J, Johnson MS, et al. Suspected acute pulmonary embolism: evaluation with multidetectorrow CT versus digital subtraction pulmonary arteriography. Radiology. 2004:233:806-815.
26. Burgan H, Akdeniz, Y.S, Ipekci A, et al. The Effectiveness of YEARS and Wells Diagnostic Criteria in the Emergency Department with Suspected Pulmonary Thromboembolism. Phoenix Medical J. 2021:3;35-9.

27. Moutzouris JP, Chwan Ng AC, Chow V, et al. Acute pulmonary embolism during warfarin therapy and long-term risk of recurrent fatal pulmonary embolism. Thromb Haemost. 2013;110:523-33.

28. Meyer G, Planquette B, Sanchez O. Long-term outcome of pulmonary embolism. Curr Opin Hematol 2008; 15: 499-503.

29. Douketis JD, Kearon C, Bates S, et al. Risk of fatal pulmonary embolism in patients with treated venous thromboembolism. J Am Med Assoc. 1998;279:458-62.

30. Koc B, Karatepe O, Unal O, et al. Post-Hospital Pulmonary Embolism Study in Patients Undergoing Prophylaxis: A Retrospective Clinical Study. Medical J Bakırkoy. 2011:7;179.

31. Baydin A, Yardan T, Eden A.O, et al. The Evaluatıon Of Cases Dıagnosed As Acute Pulmonary Embolısm In Emergency Department. Eurasian J Emerg Med. 2008;7:20-3. 